\title{
China versus China: Contending Nationalisms in The Twenty First Century Asia
}

\section{Tulus Warsito}

Jurusan IImu Hubungan Internasional, Universitas Muhammadiyah Yogyakarta Ringroad Barat Tamantirto, Kasihan, Bantul 55183

Email: tulusw_@yahoo.com

\begin{abstract}
This paper is set to find out whether the competition of Sino-Nationalism will have been influenced by the mutual benefit of their economics relations rather than by the historical hard-line military power. Post-Cold War era has shifted the ideological issue from capitalism/liberalism versus socialism/communism model to nation-wide economic welfare competition which made People's Republic of China (PRC) to redefine their national entity towards its contending part, the nationalist Republic of China (RoC). While Sino-American relations may have warmed under the Taiwan's new administration and the increasing role which Taiwan plays in Mainland China economics may have been well noted, may still lead to an undesired conflict.

Keywords: China Nationalism, Taiwan, economy, military

Abstrak

Tulisan ini dibuat untuk mengetahui apakah persaingan Sino - Nasionalisme akan dipengaruhi oleh hubungan ekonomi saling menguntungkan daripada sejarah garis kekuatan militer sejarah . Era paska Perang Dingin telah menggeserkan isu ideologis dari kapitalisme/ liberalisme melawan sosialisme/ model komunisme menjadi persaingan kesejahteraan ekonomi nasional yang membuat Republik Rakyat Cina (RRC) mendefinisikan ulang entitas nasional mereka terhadap saingan mereka nasionalis Republik Cina ( RoC). Sementara itu, hubungan Sino - Amerika menjadi lebih akrab di bawah administratif baru Taiwan dan meningkatkan peranan Taiwan di daratan utama ekonomi Cina telah dicatat dengan baik, dan akan menuntun pada konflik yang tidak diinginkan.

Kata kunci : Nasionalisme Cina, Taiwan , ekonomi , militer
\end{abstract}

\section{INTRODUCTION}

Republic of China (RoC or Taiwan) has played a prominent role in Chinese politics since the founding of the People's Republic of China (PRC) in 1949. For decades, the Chinese Communist Party (CCP) called for the "liberation" of the island, first as a means to increase its legitimacy internationally, and more recently with declining legitimacy of their socialist foundation, to deflect criticism of continued oneparty rule. When the U.S. granted formal recognition to the PRC in 1979, the PRC finally dropped the constant threat of invasion, assuming that without American support, formal independence would not occur and Taiwan would inevitably "come back home."

So far, the Taiwan Relations Act (TRA) which followed prevented any short term unification plans. After the Republic of China (ROC) on Taiwan fully democratized, the PRC gravitated towards a hardline approach, believing that the U.S. encouraged Taiwanese independence and intended to keep Taiwan separate. While cross-strait relations may have warmed under the new Prime Minister Ma Ying-jeou administration and Sino-American relations beyond the Taiwan issue have greatly improved in the past decade, the role which Taiwan plays in Chinese nationalism may still lead to an undesired conflict. 
The paper will overview of Chinese nationalism and the role of Taiwan within this narrative. Then to address how Taiwan's democratization has created tensions within this nationalist narrative. In the final part, while the continued focus on Taiwan prevents a peaceful solution, military conflict should not be seen as unavoidable.

\section{ANALYSIS}

\section{THE CONCEPT OF NATIONALISM}

Scholars and non-academics have struggled to capture the multiple facets of Chinese nationalism, as evident in the massive literature on the subject. ${ }^{1}$ Studies of nationalism attempt to subdivide the phenomenon by various means, often resulting in categories which fit only one country.

While this may provide some definitional clarity, needs to be noted that a focus on state nationalism which treats the government as the main architect of Chinese nationalism (in contrast to popular nationalism) is sufficient in this situation, especially when concerning the Taiwan issue. State nationalism highlights the need for a strong central power, consistent with the CCP's desire to justify its continued rule. Furthermore, there was little sign of an independent popular nationalism in China before the 1990s and what does exist today remains largely defined by the CCP (Chan and Bridges, 2006: 127-156).

Chinese nationalism should be viewed not as a fixed concept or a historical given, but rather as an ambiguous tool used for political purposes. Pye states that "Chinese nationalism is what the leaders of the day say it is, and this means that it becomes a defense of their formulations of what the consensus should be" (Pye, 1992: 232). By doing so, official nationalism attempts to blur the separation between the nation and rulers (Anderson, 1983: 110). A similar blurring of the lines is evident in the PRC's official account of Taiwan's post-war status, which states that the "Chinese people" recovered the lost territory of Taiwan in 1945. No distinction is acknowledged between land and people nor those under Communist rule and that under the Nationalists.
Similarly, while defining itself as a multi-ethnic state, Chinese nationalism remains at its core Hancentered, leading many to equate present nationalism with Han chauvinism (Dikotter, 2005: 177-204; Chow, 2001: 47-84). This conception of Chinese nationalism, however, remains an admitted simplification. While this article starts from a position of elitedriven nationalism, one must acknowledge that nationalism in almost any context defies such narrow instrumental definitions. Societal influences increasingly shape Chinese nationalism, but more in terms of responding to state-driven directives rather than presenting an organic alternative. The focal points of contemporary Chinese nationalism may be dictated by the leadership, but how these factors resonate with the general populace largely defines the depth of such sentiments, creating restraints beyond what elites may have originally intended.

New regimes often push nationalism to overcome perceived historical wrongs subjected to by other powers. Mondal described Indian nationalism similarly as ideologically a pole away from colonialism (Mondal, 2003: 144). Although only small parts of China were de facto colonized by Western powers (i.e., Hong Kong and Macao), China's history with Western imperialism (and later Japanese imperialism) has a similar influence on Chinese nationalism, leading some to state that anti-imperialism defines Chinese nationalism. ${ }^{2}$ The success of the CCP transformed Chinese nationalism from primarily antiJapanese in nature to include its Nationalist opposition and the U.S. under the broad category of imperialism. Furthermore, CCP propaganda framed the party as the vanguard against Japanese occupation, while the Nationalists were portrayed as preferring to fight fellow Chinese, contributing to the enduring anti-Japanese element within Chinese nationalism. ${ }^{3}$

Rhetoric of "liberating Taiwan" cannot be understood outside of the context of the Chinese civil war. The CCP master narrative of creating a socialist society focused on ridding the mainland of imperialist encroachment and the establishment of the PRC in 1949 was constructed as the defining historical 
turning point. Since the ROC was supported by the U.S. and Chiang Kai-shek was already labeled an imperialist, the only means to complete the narrative was to maintain support for military force to reclaim the island. Thus, the CCP continued to portray the Taiwan issue as a historical injustice, claiming both that Taiwan for centuries had been Chinese until Japanese annexation in 1895 and that biological and geological evidence supported their position of the Chineseness of Taiwan. ${ }^{4}$

An argument can be made that Taiwan was unimportant to the CCP until the Nationalists were forced to the island, in part because of Mao's comments in the 1930s that Taiwan was beyond the boundaries of China, in the same category as Vietnam and Korea (Snow, 1938: 33-89). Other CCP documents suggest that Taiwan was seen as a peripheral entity. The "Message to Compatriots on Resistance to Japan to Save the Nation" and the "Resolution of the CC on the Current Political Situation and the Party's Tasks" in August and December of 1935 both refer to Taiwan in similar tones as Korea and should be united in an anti-Japanese alliance. In the "CCP Declaration on the War in the Pacific" in December of 1941, the CCP states their goal of encouraging anti-Japanese propaganda and agitation, again mentioning Taiwan in a similar fashion as Korea. The Constitution of the CCP in June of 1945 also makes no reference to the island.

China has also assumed that any cross-strait military conflict will include American involvement. From the onset of the Cold War through the 1970s, the CCP implicitly desired formal recognition from the West. Despite constant references to the moral and political corruptness of American "imperialism," Beijing realized that its security would be strengthened by formal relations. This desire went so far that the PRC hinted in the 1950s that it would renounce claims to Taiwan in exchange for formal relations with the U.S. (Madsen, 2001: 159; Purifoy, 1976: xi).

However, one can presume this option was discarded due to its potentially negative domestic ramifications for the CCP as much as U.S. disinterest. The impor- tance of relations with the U.S. can also be seen in the shift in the CCP party line. Shortly after recognition, the PRC abandoned the slogan "liberation of Taiwan" in favor of peaceful unification, suggesting Beijing's confidence that without American support, such a policy could be successful.

America dropping its opposition to seating the PRC, followed by the 1972 Communiqué ("The Shanghai Communiqué") and the 1979 Communiqué establishing formal recognition gave Beijing officials the impression that although unification may not be immediate, the likelihood of permanent separation was diminishing. American intent, however, was more a policy of engagement and vague dialogue rather than capitulation on Taiwan, ${ }^{5}$ with the U.S. simply acknowledging the Chinese position of "One China." As Hickey stated, the term "acknowledge" was deliberately chosen to indicate "cognizance of, but not necessarily agreement with, the Chinese position."6 The Taiwan Relations Act (TRA) further shattered Chinese hopes and made American agreements on both military supports of Taiwan (the U.S. agreed in 1972 to remove all U.S. forces from Taiwan) and recognition of a "One China" policy seem disingenuous. The TRA essentially left these relations intact, which the PRC took as a clear violation of their sovereignty, with later agreements and actions (e.g., the 1982 Communiqué, President Bush's approval of military assistance in 1992) lending further support to American disingenuousness. With these seemingly contradictory positions, Beijing officials surmised that Washington opposed a Beijing-led reunification and thus the U.S. returned as a prime obstacle in the unification narrative. The only way to overcome this obstacle was to raise the costs for American intervention and Taiwanese actions inconsistent with unification.

Although Chinese rhetoric about the U.S. did not return to pre-normalization levels, their unfulfilled expectations continue to taint Sino-American relations with a level of distrust which has only been exacerbated by America's support of Taiwan's democratic reforms. 


\section{DEMOCRATIZATION}

The maintenance of China's Taiwan policy and the necessity of unification has aided the PRC in deflecting domestic criticism, in particular the lack of democratic reforms. Beijing traditionally argued that Chinese and Confucianist culture were not suited for a Western-style democracy.

However, East Asian democratization, including Taiwan's own transformation, undermines this stance. ${ }^{7}$ Taiwan's first democratically elected president Lee Teng-hui used this to his political advantage, making potential reunification contingent on mainland democratization (Shih, 2003:31). Since then, the CCP leadership has altered its argument, stating that democracy brings chaos, with many drawing a parallel to the Cultural Revolution and the potential chaos of democratic reform, with the decline of Russia as further evidence.

Implicit in China's democracy-brings-chaos theory is that foreign interests are behind such reforms to keep the country weak by ousting the CCP. Similarly, during the Tiananmen protests, Beijing officials drew a direct correlation between Taiwan's young democracy and a looming threat to their hold on government. ${ }^{8}$ Protestors were viewed as akin to outside agitators, making the use of force to disperse the crowds more acceptable. While cross-strait talks emerged in 1991, China has refused to view democratization as anything but a potential threat.

Furthermore, the PRC leadership has attempted to dismiss any suggestion that democratization could alter claims over Taiwan. In practical terms, however, it has lead to the ROC that, while still paying lip service to "One China," has denounced claims to the mainland and maintained an ambiguous stance on Taiwan's future-consistent with a public which both sees itself increasingly as Taiwanese or both Chinese and Taiwanese and that prefers the continuation of the status quo. Any position on Taiwan's future status inconsistent with Taiwanese public opinion would be political suicide. As Lee Teng-hui stated "Taiwan has now reached the point of no return. The people of Taiwan would never countenance any less representa- tive form of government" (Teng-hui, 1999: 9-14).

Instead, the PRC maintains symbolic representation of Taiwan within the national legislature, enlisting delegates with no connection whatsoever to the island. ${ }^{9}$ Furthermore, accepting that Taiwan's democracy had changed its status would require Beijing to admit that their demands for party-to-party talks (instead of government-to-government) were inappropriate. On a practical level, Beijing must treat democratization as a non-issue in terms of Taiwan's political status or accept radical changes to the cross-strait dialogue which does nothing to help their own goals.

Maintaining this stance seems to invite conflict with Taiwan. It should not have been surprising then when Lee Teng-hui set equally unacceptable conditions for unification talks (democratic reforms on the mainland and renouncing the use of force) (Chu, 2000: 313). Beijing's response, to label Lee a "lackey of America" (Shambaugh, 1998: 242), allowed for the maintenance of the narrative by eliminating Lee as a person to take seriously. It also started a pattern of discrediting Taiwan's leaders who refer positively to Taiwan's separate status as nothing more than independence-seekers. For example, Chen Shui-bian's proposal of "cross-strait integration" seemed to please PRC leaders, but once Chen clarified that this meant rapprochement not unification, the PRC returned to a hardline rhetoric. Although talk of "liberating" Taiwan ceased with formal relations with the U.S., Beijing's efforts to maintain public support for the use of force in order to prevent Taiwan's permanent separation continues. Furthermore, many Taiwanese officials have been demonized to the point that mainland Chinese view anyone willing to negotiate with Taiwan regarding the island's future status implies sovereign equality and thus is labeled a traitor (Friedman,2001: 135). Even cross-strait negotiations which skirt sovereignty issues risk this backlash as any actions not clearly consistent with unification is assumed to encourage independence. Conciliatory efforts in the past were often undermined by the "victor's mentality" of old cadres that were still in prominent positions through the mid 1980s which were adamantly opposed to any 
conciliatory effort which implied equality for ROC officials (Shih, 2003: 52). Despite a marked drop in revolutionary rhetoric out of Beijing, Taiwan's position in the calculus of Chinese nationalism has remained constant. This does not mean that the PRC has been inflexible in its Taiwan policy. Beijing seems willing to make overtures to Taiwan as long as it conforms to their master narrative of a CCP victorious in the protracted Chinese civil war. Similarly, mainland propaganda attempts to solidify the view that the CCP is China. Any suggestion that the party was not the true voice of China would be incongruent with the master narrative. ${ }^{10}$ For example, in talks during the early 1980s, the PRC seemed willing to grant Taiwan some form of autonomy after reunification, allowing "One China" to be defined beyond a political scope, highlighting historical and cultural ties. Once it became clear Taiwan did not wholeheartedly support imminent reunification, China ended such talk and insisted that "One China" had a clear political definition. More importantly, the CCP continues the decade's old notion that once Taiwan reunites with the mainland, China will once again rise to the status of a world power and their era of weakness will be over. As Zong Hairen declared, "The Taiwan issue is a threshold China must step over if it is to go out into the world. If China fails to cross this threshold it cannot go into the world or genuinely become a world power; even less can it compete with the United States" (Hairen, 2002: 16). While unification does provide some strategic advantages, even a peaceful unification cannot live up to the "cure all" that Beijing officials have made it out to be. Perpetuating this nationalistic dream places further pressures on CCP leaders to bring Taiwan back into the fold. Both Deng Xiaoping and Jiang Zemin wanted unification on their watch to secure their place in history, yet neither was willing to take a more conciliatory approach which would conflict with the implicit "liberation" narrative. With the return of Hong Kong and Macao under the "one country, two systems" formula, Jiang put added pressure on himself because the formula made Taiwan's unification look inevitable (Gungwu, 2004).
While Hu Jintao has avoided an implicit timeline, he too must show evidence that Taiwan is not forever lost. The growing economic integration between both sides has also done little to curb this nationalist trend, as it, along with the PRC's own domestic economic growth may actually strengthen Chinese nationalist sentiment as it reinforces that China is on its way to economic and political superpower status. As Lam suggests, the next generation of Chinese leaders, equipped with greater economic power, have little reason to decrease their nationalist tone (Lam, 2003: 264-265). A PRC on the rise then may be more inclined to push the Taiwanissue. ${ }^{11}$

By encouraging such nationalist sentiment and being unable to deliver, Beijing officials have produced an unintended side effect. Since the government relies so heavily on nationalism, reining in public variants is particularly problematic (Zhang, 2007: 27-30). Nationalism by its very nature plays upon history, but if the nationalistic message is unattainable, these unfulfilled national desires impose higher pressures for the future. Shih argues that if enough unfulfilled nationalism accumulates within a society, these grievances will lead to complete devotion to further nationalist causes (Shih, 2003: 81). In other words, Beijing's nationalist rhetoric has created a spiraling effect, encouraging greater support of the party line in regards to Taiwan policy, but also placing greater demands on the government to conform to this hardline approach when a more conciliatory policy may be more effective in achieving the mainland's goals.

Viewing Chinese nationalism as a response to legitimate concerns over territorial integrity is also misleading. The PRC has continuously used the principle of preserving territorial integrity in its argument over Taiwan (Hsiao, 1998: 715). With the return of Hong Kong and Macao, Taiwan remains the last major territory claimed by the PRC not under its control, the last remnant of China's humiliating defeats in the 19th and 20th centuries. However, the CCP not only accepted the loss of land before "losing" Taiwan to the Nationalists (i.e., Outer Mongolia), they have also willingly relinquished other territorial 
claims in recent years. ${ }^{12}$ Since Taiwan was never under control of the CCP or PRC, it also differs from the traditional view of a separatist movement. The PRC did not lose control of Taiwan; they never had it. Furthermore, Taiwan cannot be seen as a threat to Chinese security unless backed heavily by the U.S. ${ }^{13}$

Attempting to explain China's Taiwan policy as primarily a function of nationalism admittedly oversimplifies the situation. A common argument is that the mainland's fear of looking weak on Taiwan prohibits any negotiations on the matter and that the CCP leadership would lose all credibility if it is weak on the Taiwan issue. The core of this argument is that if Taiwan were to reject conciliatory offers from the mainland, the PRC would lose face. A mishandling of the issue could also strain the power coalition within the CCP, a major concern during the Jiang-Zhu era (Wang and Yongnian, 2000: 7), but a concern which persists today. However, several incidents have made the PRC's stance look weak and yet the legitimacy of the leadership was not inquestion. The mainland's backing down during the Quemoy and Matsu crisis 1954-1955, the enactment of the Taiwan Relations Act, and America's increased military sales after the 1982 Communique all contradicted the notion that Chinese nationalism would require a hardline response. In each case, the mainland response was limited primarily to harsh criticism, suggesting that the PRC is maintaining the policy of being "firm on principles, flexible on tactics." A key difference, however, is that in all of the cases mentioned, Taiwan was not the party that made China look weak. Rather it was America's influence. In the aftermath of democratization, Taiwan's success as a separate entity presents a continued challenge to the PRC narrative, one arguably more detrimental to the PRC's master narrative than previous incidents. This is exacerbated by the need for Taiwanese officials to maintain domestic support on matters which can upset the delicate balance of cross-strait dialogue. Taiwan's military purchases from the U.S. under the Ma Ying-jeou administration for example directly conflicted with the government's more pro-China stance, leading the
PRC to respond with traditional harsh rhetoric common during the previous Chen Shui-bian administration. Beijing's ultimate objectives for Taiwan also remain somewhat unclear. The PRC certainly wants unification, but, outside of the proposed "One China, Two Systems" formula, has been vague on the structure of this unified China. The mixed success of Hong Kong under this system has done little to entice Taiwan to move towards unification, suggesting that another formula may be more appropriate. However, the PRC calls other formulas unacceptable (e.g., federalism), thus denying the possibility of a formula that allows for the basic continuation of Taiwan's de facto independence while committing both sides to unification. Pushing for a hasty unification, however, brings greater problems for Beijing. Any large scale military action to retake Taiwan would conflict with mainland propaganda, revealing that the Taiwanese public was not on the side of the PRC..$^{14}$ Even if the PLA can quickly overcome forces on the island and cross-strait conflict does not encourage protests in Tibet and Xinjiang dividing People's Liberation Army (PLA) attention, reincorporating a defeated Taiwan into a greater China will be politically and economically exhaustive. The only clear objective behind military threats or even more recent enticements, thus is to maintain hope for unification by preventing formal independence (Swaine, 2004: 40).

\section{THE CONTENDING EPISODE}

Historically, the CCP has used force (or the threat of it) to test an opponent's resolve and the Taiwan issue is no different. The first major test occurred over Matsu and Quemoy in 1954-1955 which arguably backfired, resulting in greater American support for the ROC and a weak threat to use nuclear weapons to stop Chinese aggression. In 1954 America lifted its blockade of Taiwan, making a more ambitious attempt to reclaim the mainland possible. Chiang Kai-shek amassed large numbers of troops on the offshore islands leading up to the crisis, which perhaps convinced the CCP a heightened conflict was imminent. ${ }^{15}$ Others suggest that following the Korean War, the 
PRC's primary motive was to test the strength of America's renewedcommitments to the ROC (Kovachi, 2002: 7; Copper, 2003: 48).

Regardless of the cause, this show of force accomplished two things for the CCP. First, it reinforced the view of American intent on containment and made possible the symbolic use of Taiwan to drum up antiAmerican sentiment for China's continued humiliation. Second, it encouraged the ROC to maintain the offshore islands. Chiang Kai-shek saw the islands as a symbolic link to the mainland and his claims to legitimately rule it. To relinquish them after this military conflict would not only signal to the CCP military weakness, but would likely encourage those within Taiwan to consider Taiwan as a separate country, a consideration dismissed post 1954.

With Sino-American rapprochement in 1979, the PRC ended talk of the need to "liberate" Taiwan in favor of allowing for peaceful reunification. However, as Taiwan's democratized, China's willingness to remind Taiwan that forceful reunification was still an option became more common. While China's threats have changed little, its capabilities to fulfill such threats have grown. The combination of Chinese nationalism and a belief that war may be inevitable leads Beijing to continue its hardline approach. To increase its deterrence capabilities, China has spent an exorbitant amount on weaponry, reducing, if not eliminating any technological advantages possessed by Taiwan. Recent acquisitions have led some PLA officials to believe that within the next decade, the PRC will not only have military superiority over Taiwan, but will be able to repel "foreign intervention” as well. Taiwan has responded with attempts to improve its deterrent capabilities. While the PLA's projection is unlikely, the rapid military advances are a cause for concern.

Military improvements have created a chauvinistic mentality that China can act more unilaterally concerning Taiwan than before. Beijing believes that this will make the U.S. less likely to support Taiwan, turning the ROC from "bold and aggressive" to "demoralized and cautious" (Garver, 1997: 13).
Although the PLA's capabilities have increased considerably in recent years, the focus of military development remains rather limited. Much of the effort has been on missile development and cyber-war capabilities, not equipment needed for an invasion, which suggests that Beijing's motive remains deterrence. This also shows the limitations of Chinese military threats to others in the region. The PRC may be looking for a rationale for war, but their military build-up heavily favors deterrence or short-term conflict, not a full invasion.

Even assuming that China's military build-up is intended solely for deterrence purposes, this does little to decrease tension in the region. China has never clearly defined what it would take for a military response and now with greater abilities to inflict damage on Taiwan, China may lower this threshold. For example, the Anti-Secession Law of 2005 appears to label any move that may appear as directed towards independence or Taiwan's unwillingness to unify as a potential cause for military action. ${ }^{16}$

Secondly, Taiwan feels inherently less secure because of this build-up and thus seeks more military procurements and greater protection from the U.S. More generally, China's military build-up and the militant Chinese nationalism supporting it encourages Taiwanese to see themselves as different than Chinese on the mainland. ${ }^{17}$ This arguably creates a spiraling effect as Taiwan's efforts to assert themselves increase the mainland's belief that Taiwan is creeping towards independence. The mainland thus takes a harder stance and increases its missiles directed at Taiwan, further encouraging Taiwanese to see themselves as different from those on the mainland.

\section{CONCLUSION}

In the absence of Communist ideology, nationalism has become the primary means to unify a population into accepting, if not approving, the continued leadership of the CCP. This tool, however, has no clear long-range objective other than unification and thus one cannot easily predict what role Chinese nationalism will play in the future. As Scalapino 
stated, as China becomes a greater political power, this nationalism could manifest itself in either benign (e.g., a focus on a rich cultural heritages) or militant form (Scalapino, 1998: 204). Presently, the PRC's nationalist narrative requiring unification precludes the possibility of a negotiated political settlement regarding Taiwan's sovereignty, even one that ultimately leads to unification. The negative rhetoric towards previous Taiwanese presidents simply increased support for these men in a way that a cordial approach never could, by creating a clear "us and them" image Taiwanese politicians could play upon. The mainland's decision to continue a hardline approach in 2000 likely lead to their least desired candidate being elected (pro-independence candidate Chen Shuibian), leaving Beijing officials confused at their lack of success (Wang, 2001: 726). This may in part explain not only China's more flexible policy since the election of Ma Ying-jiu in Taiwan, but President Ma's own pro-China policy initiatives.

Beijing has been given ample opportunities to make overtures to the ROC short of acknowledging them as a legitimate national government. Recent party-toparty talks and increased commercial ties show that constructive dialogue, however flawed, may be possible. The culmination of the Economic Cooperation Framework Agreement (ECFA) and the possibility of an emerging "Chaiwan" economic union suggest a major thaw in cross-strait dialogue and may encourage both sides to conduct constructive dialogues on sovereignty issues. China's rise as a world power in part requires peaceful regional economic if not political integration, Taiwan included. While some expect economic integration to encourage political solutions (Cheung, 2010: 11-36), such hopeful thinking, however, ignores the continued attempts by the PRC to at least rhetorically separate economic and political spheres. Even the means in which ECFA was negotiated intentionally resembled party-to-party talks rather than intergovernmental negotiations, further dismissing the dynamics of a democratic Taiwan (Cohen, Jerome A. and Chen, 2010). Furthermore, greater economic integration may leave Taiwan sensing fewer political options.

While China attempts to keep economic and political discussions separate, consistent with official nationalism, in practice this has been problematic, not only in terms of concerns within Taiwan but the expectations within China that economic integrations is simply an intermediary stage before political integration. Although increased economic integration may create greater pressures for both sides to find acceptable political solutions to the Taiwan issue, little evidence suggests that China's stance vis-à-vis Taiwan's sovereignty will change.

In contrast to ever more sophisticated approaches to international relations elsewhere, China's Taiwan policy remains poorly developed for current conditions (Hickey, 2009: 31-70). Despite recent thaws in cross-strait relations and the PRC's own belief that time is on their side, the dismissal of Taiwan's democracy confounds the mainland's goals as it has allowed a counter nationalism to foster. Such backlash is apparent in Taiwan as the perceived economic benefits from recent cross-strait exchanges have not overcome sovereignty concerns. China may believe that their increased economic and political power will propel them to superpower status and in the process Taiwan will be forced back into the fold, but the interplay of Taiwan's democratization and the counter nationalism encouraged indirectly by Beijing's own actions make this highly doubtful.

\section{ENDNOTES}

1 Zhou Enlai had mentioned the possibility of peaceful "liberation" in 1956, but the term was generally seen to imply eventual unification by force (Guillermaz, 1976: 181).

2 Zhao argues that Chinese nationalism was sparked by foreign invasions (Zhao, 2000: 253; Shih, 2003: 84).

3 This narrative endured even though the KMT played a far more instrumental role in this than their communist counterparts. KMT contributions to liberation were largely ignored until 2005 (Chang and Halliday, 2005: 211-213; Chan and Bridges, 2006: 135).

4 This evidence intentionally omits contrary evidence. First, that Taiwan's indigenous peoples do not have a Chinese mainland origin. Secondly, even if geological evidence shows a historical linkage between Taiwan and China, this predates the Chinese state.

5 This could also be inferred by the broadness of the 1972 Communiqué, in that both sides mention the general need to reduce tensions and increase peace in Asia, discussing Korea, India- 
Pakistan conflict and Indochina almost as much and in similar vague terms as the Taiwan issue. Guillermaz referred to this as both sides making a "tentative sketch of what East Asia could become." Guillermaz 1976: 549; "Nixon's China Game," documentary, WGBH Educational Foundation and Ambrica Productions, 2000.

6 Similarly the PRC made similar "acknowledgements" of continued American arms sales to Taiwan to quicken the normalisation process. Dennis Van Vranken Hickey, "U.S.-Taiwan Security Ties: Toward the Next Millennium" (paper presented at the conference Taiwan on the Threshold of the 21st Century: A Paradigm Reexamined, National Chengchi University, Taipei, Taiwan. 4-5 January, 1999), available online at http://www.taiwansecurity.org/IS/ IS-Hickey.htm.

7 Democratic reforms in pre-1997 Hong Kong further damage such claims.

8 Although Taiwanese may have emotionally supported the Tiananmen demonstrators, there is no evidence that the ROC supported protestors with money or material (Copper, 2003: 5455.

9 The ROC would also likely prevent would-be delegates from Taiwan from filling these seats as well as this would be explicitly acknowledging the PRC's conception of "one country, two systems." "China's Mystery Delegates a Puzzle to Most Taiwanese," Taipei Times, 1 March, 2003.

10 David Shambaugh, "Civil-Military Relations in China: Party-Army or National Army?" in Bringing the Party Back in: How China is Governed, ed. Kjeld Erik Brosgaard and Zheng Yongnian (National University of Singapore, 2004), 24

11 An aide to Jiang Zemin stated, "The Taiwan problem will automatically be solved once China is recognised around the world as on par with the U.S. Can you imagine any country daring to sell arms to Hawaii if there was a pro-independence movement on the island?"; Willy Wo-Lap Lam, "Jiang pulls out all the stops in foreign policy," South China Morning Post, 25 January, 1999, http:// special.scmp.com/chinaat50/Article/FullText_asp_ArticleID19990928210012708.html.

12 Since 1991, China has settled border conflicts with six nations and in most received half or less of the contested territory. In its agreement with Tajikistan, China conceded to only 1,000 of the 28,000 square miles of territory in dispute (Medeiros and Fravel, 2003).

13 While bombing the Three Gorges Dam has been suggested as a means to deter China, there is no evidence that Taiwan has considered a pre-emptive strike. "No Plan to Attack Three Gorges Dam: MND," China Post, June 10, 2004; "China General Threatens War if Taiwan Targets Three Gorges," China Post, June 17, 2004; "Terrorism Part on Taiwan Separatist Agenda," Xinhua News Agency, 18 June, 2004; Peter H. Gleick, "Three Gorges Dam Project, Yangtze River, China," Water Brief 3, The World's Water 2008-2009 (2008): 139-150; Wendell Minnick, "Taiwan Continues Cruise Missile Effort," DefenseNews, 23 March, 2009

14 The call to "liberate" Taiwan and references to Taiwanese compatriots always suggested that the majority of the island's inhabitants were supportive of the PRC. The implication is that the ROC government and other "imperialist" or independence minded Taiwanese were the source of the conflict.
15 This does not necessarily mean either side expected the ROC to attempt to recapture the mainland, onlythat backed by the U.S. the Nationalists could take more provocative actions against the mainland.

16 Article 8 states that "In the event that the 'Taiwan independence' secessionist forces should act under any name or by any means to cause the fact of Taiwan's secession from China, or that major incidents entailing Taiwan's secession from China should occur, or that possibilities for a peaceful reunification should be completely exhausted, the state shall employ non-peaceful means and other necessary measures to protect China's sovereignty and territorial integrity." Embassy of the People's Republic of China in the United States of America website, http://www.china-embassy.org/eng/zt/ twwt/t187406.htm.

17 For more on the rise of Taiwanese identity and its relation with the island's future status vis-à-vis China, see Election Study Center (National Chengchi University) "Taiwanese/Chinese Identification Trend Distribution in Taiwan (1992/06-2009/12)," available online at http://esc.nccu.edu.tw/english/modules/tinyd2/content/ TaiwanChineselD.htm; (Niou, 2005: 91-104).

\section{BIBLIOGRAPHY}

Anderson, Benedict. 1983. Imagined Communities: Reflections on the Origin and Spread of Nationalism. London: Verso.

Chan, Che-po and Brian Bridges, 2006. China, Japan and the Clash of Nationalisms. Asian Perspectives, Vol. 30, No. 1.

Chan, Che-po and Brian Bridges. 2006. China, Japan, and the Clash of Nationalisms. Asian Perspectives, Vol. 30, No. 1.

Chang, Jung and John Halliday, 2005. Mao: The Unknown Story. London: Jonathan Cape.

Cheung, Gordon C. K. 2010. New Approaches to Cross-Strait Integration and Its Impacts on Taiwan's Domestic Economy: An Emerging 'Chaiwan'?. Journal of Current Chinese Affairs 39, no. 1.

China Post. June 10, 2004. No Plan to Attack Three Gorges Dam: MND.

China Post. June 17, 2004. China General Threatens War if Taiwan Targets Three Gorges.

Chow, Kai-Wing. 2001. Narrating Nation, Race and National Culture: Imaging the Hanzu Identity in Modern China. In Kai-Wing Chow, Kevin M. Doak and Poshek Fu (ed), Constructing Nationhood in Modern East Asia. Ann Arbor: University of Michigan Press.

Chu, Jou-juo. 2000. Nationalism and Self-determination: The Identity Politics in Taiwan. Journal of Asian and African Affairs, August.

Cohen, Jerome A. and Yu-Jie Chen, 2010. ECFA and Taiwan's Political System. U.S. Asia Law Institute, July 6. (Online), (http:// www.usasialaw.org/?p=3814).

Copper, John F. 2003. Taiwan: Nation-State or Province? $4^{\text {th }}$ edition. Boulder, CO: Westview Press.

Dikotter, Frank. 2005. Race in China. In Pal Nyiri and Joana Breidenbach (ed), China Inside Out: Contemporary Chinese National and Transnationalism. Budapest: Central European University Press.

Friedman, Edward. 2001. The Possibility of Peaceful Compromise in Cross-Strait Relations. In Kenneth Klinker (ed), The United States 
and Cross-Strait Relations: China, Taiwan and the U.S. Entering a New Century. Urbana-Champaign: University of Illinois, 2001.

Garver, John W. 1997. Face Off: China, the United States, and Taiwan's Democratization. Seattle: University of Washington Press. Gleick, Peter H. 2008. Three Gorges Dam Project, Yangtze River, China. Water Brief 3, The World's Water 2008-2009

Guillermaz, Jacques. 1976. The Chinese Communist Party in Power, 1949-1976. Boulder, CO: Westview Press.

Gungwu, Wang. 2004. Systems and Cultures: A Perspective on Recent Chinese History. Sspeech, Ohio University, 7 May.

Hairen, Zong. 2002. Responding to the 'Two States Theory'. Chinese Law and Government, Vol 35, no. 2 (March-April).

Hickey, Dennis V. 2009. Beijing's Evolving Policy Toward Taipei: Engagement or Entrapment. Issues \& Studies, vol. 45, no. 1.

Hickey, Dennis Van Vranken and Yitan Li, 2002. Cross-Strait Relations in the Aftermath of the Election of Chen Shui-bian. Asian Affairs: An American Review, Vol. 28, no.4 (Winter).

Hickey, Dennis Van Vranken. 1999. U.S.-Taiwan Security Ties: Toward the Next Millennium. Paper presented at the conference Taiwan on the Threshold of the 21st Century: A Paradigm Reexamined, National Chengchi University, Taipei, Taiwan. 4-5 January. (Online), (http://www.taiwansecurity.org/IS/IS-Hickey.htm).

Hsiao, Anne Hsiu-An. 1998. Is China's Policy to Use Force Against Taiwan a Violation of the Principle of Non-Use of Force Under International Law?. New England Law Review, 32 (Spring).

Kovachi, Noam. 2002. A Conflict Perpetuated: China Policy During the Kennedy Years. Westport: Praeger.

Lam, Willy Wo-Lap. 1999. Jiang pulls out all the stops in foreign policy. South China Morning Post, 25 January. (Online), (http:// special.scmp.com/chinaat50/Article/FullText_asp_ArticlelD19990928210012708.html).

Lam, Willy Wo-Lap. 2003. The Generation after Next in Chinese Politics. In David M. Finkelstein and Maryanna Kivlehan (ed), Chinese Leadership in the $21^{\text {st }}$ Century. New York: M. E. Sharpe.

Madsen, Robert A. 2001. The Struggle for Sovereignty Between China and Taiwan. In Stephen D. Krasner (ed), Problematic Sovereignty: Contested Rules and Political Possibilities. New York: Columbia University.

Medeiros, Evan S. and M. Taylor Fravel, 2003. China's New Diplomacy. Foreign Affairs Vol 82, no. 6 (November-December).

Minnick, Wendell. 2009. Taiwan Continues Cruise Missile Effort. DefenseNews, 23 March.

Mondal, Anshuman. 2003. Nationalism and Post-Colonial Identity: Culture and Ideology in India and Egypt. London: RoutledgeCurzon.

Niou, Emerson. 2005. A New Measure of the Preferences on the Independence-Unification Issue in Taiwan. Journal of Asian and African Studies, Vol 40, no. 1-2.

Purifoy, Lewis McCarroll. 1976. Harry Truman's China Policy: McCarthyism and the Diplomacy of Hysteria, 1947-1951. New York: New Viewpoints Publishing.

Pye, Lucian. 1992. The Spirit of Chinese Politics. Cambridge: Harvard University Press.

Scalapino, Robert A. 1998. Will China Democratize? Current Trends and Future Prospects. In Christian Soe (ed), Comparative Politics 98/99. Guilford: Dushkin/McGraw-Hill.
Shambaugh, David. 1998. Taiwan's Security: Maintaining Deterrence Amid Political Accountability. In David Shambaugh (ed), Contemporary Taiwan. Oxford: Oxford University Press.

Shambaugh, David. 2004. Civil-Military Relations in China: Party-Army or National Army?. In Kjeld Erik Brosgaard and Zheng Yongnian (ed), Bringing the Party Back in: How China is Governed. Singapore: National University of Singapore.

Shih, Chih-yu. 2003. Navigating Sovereignty: World Politics Lost in China. New York: Palgrave MacMillan.

Snow, Edgar. 1938. Red Star Over China. New York: Random House.

Swaine, Michael. 2004. Tough Love for Taiwan. Foreign Affairs 40 (March-April)

Teng-hui, Lee. 1999. Understanding Taiwan: Bridging the Perception Gap. Foreign Affairs 78, no. 6 (November-December).

Wang, John and Zeng Yongnian. 2000. The Waning of the Jiang-Zhu Coalition? Singapore: Singapore University Press.

Wang, T. Y. 2001. Cross-Strait Relations After the 2000 Election in Taiwan: Changing Tactics in a New Reality. Asian Survey vol. 41, no. 5 (September-October).

Xinhua News Agency. 18 June, 2004. Terrorism Part on Taiwan Separatist Agenda.

Zhang, Jian. 2007. The Influence of Chinese Nationalism on SinoJapanese Relations. In Michael Heazle and Nick Knight (ed), ChinaJapan Relations in The twenty first Century: Creating a future Past? Cheltenham: Edward Elgar Publishing.

Zhao, Suisheng. 2000. Chinese Nationalism and Authoritarianism in the 1990s. In Suisheng Zhao (ed), China and Democracy: the Prospect for a Democratic China. New York: Routledge. 